\title{
Application of the Differentiated Learning Model in Advanced BIPA Courses
}

\author{
Prima V. Asteria ${ }^{1, *}$ Ahmad G. Muzakki ${ }^{1}$ Trinil Turistiani $^{2}$ Alda Setyawati $^{3}$ \\ 1,2,3 Indonesian Language and Literature Education, Universitas Negeri Surabaya, Indonesia \\ Corresponding author.Email: primaasteria@unesa.ac.id.
}

\begin{abstract}
The aims of this study are (1) to describe the process of identifying the profile of students' characteristics in Advanced BIPA courses and (2) to describe the process of developing differentiated learning models in Advanced BIPA courses. The research method used is the ADDIE model development method, which includes two stages, namely the Identification of Learner Characteristics Phase and the Differentiated Learning Model Development Phase in the Advanced BIPA course. The characteristic profile of students in Advanced BIPA courses is based on their learning profile, learning interest, and learning readiness. The data taken is under the needs or learning needs. It is mainly associated with various experiences of students, hobbies, routine activities, interesting activities, places, and events related to personal experiences. Along with the demands of differentiated learning by the conditions and characteristics of students, teachers are required to play a more dynamic and creative role. Learning activities are needed based on students' learning needs to optimize learning and students' learning outcomes. Adjustment of learning scenarios can take advantage of the characteristics or several profile attributes in common with other individuals. It proves that the availability of student characteristic profiles can encourage creativity and innovation from teachers.
\end{abstract}

Keywords: Profile, Characteristics, Differential learning

\section{INTRODUCTION}

Advanced courses of Indonesian for Foreign Speakers (BIPA) are courses followed by prospective BIPA teachers. Through this course, prospective BIPA teachers are educated to become professional BIPA teachers. Professional educators mean being able to apply theoretical principles into applied aspects of the learning component. Generally, research conducted in BIPA discusses elements of the material, method, media, assessment, and mastery of the material, as research conducted by [1]-[5]. In the study, BIPA students were described as subjects of "finished" educational activities. Therefore, BIPA students only followed the educational process provided and "must" be able to adapt so that they were expected to achieve the competencies that had been previously targeted even before they decided to become BIPA students. Therefore, the BIPA advanced course aims to make students as the core of all learning activities.

It is very rare for teachers and educational institutions to regard BIPA students as learning centers in the true sense of the word. What happened was that in Amin's research, BIPA students did not understand vocabulary, then the teacher compiled their materials, methods, and media to increase their vocabulary [6]. Or, as in the research of Nursyairofi, et al., BIPA student motivation is measured during various learning processes that have been prepared by teachers or educational institutions [7]. Even in Wiratsih's research, which found Chinese BIPA students had difficulty pronouncing some consonants of the Indonesian alphabet, there was no followup in learning activities or classroom action research [8]. In the end, BIPA learning tends to place BIPA students as learning inputs and outputs, not part of the learning process, which seems to be the prerogative of teachers, institutions, and policymakers.

The educational paradigm has undergone a very significant shift. Education which initially aims to improve attitudes, mindsets, and human behavior, tends to change to meet the demands of the times. This has resulted in the education system being formed only focusing on how a competency "which is considered important". Whoever the person is, regardless of the condition, when entering the education system, it is the individual who must be willing and 
able to adapt to the already available system. Even if the competency is not necessarily used or needed throughout his life. The education system no longer views the individual as a privilege, who is born and equipped with uniqueness, which is the basic capital and the main capital in living the whole life later. The existing education system is becoming more and more similar to a life selection tool. If able to adapt, it is considered a guaranteed future, while if not capable, then the future seems to be doomed to fail. Humans are no longer the subject of education, but only an input that is successfully processed or failed in an education system. Therefore, educational institutions and educators should be innovative, learning needs, process, and target to be made enjoyable and student-centered [9], [10].

Every individual has differences, ranging from talents, abilities, family conditions, physical conditions, and the ability to think and feel. This uniqueness will grow and diversify. Some advantages are trained to become experts. Some disadvantages are trained to become strengths, there are also advantages that are wasted so that they become weak. Some shortcomings are increasingly left behind because they have never been honed. This is where the role of education as a means to humanize humans. According to the KBBI, education is the process of changing the attitudes and behavior of a person or group of people to mature human beings through teaching and training efforts; process, method, an act of educating. Education is a transfer of knowledge, transfer of value, transfer of culture, and transfer of religion with human subjects. Even Bloom implicitly shows that the competencies needed as capital in human life consist of cognitive, affective, and sensory domains [11]. This is what needs to be straightened out, that humans are the center of learning, and the education system functions to shape humans according to their respective characteristics. Standardization is indeed essential, but it is used to evaluate the components of the education system, not to judge or judge the individual who is the subject. Measurement of the subject is only limited to knowing the extent of the competency level controlled by the individual when the assessment is carried out. The point is that the assessment results are used to evaluate whether the education system, learning models, strategies, methods, materials, educator competencies, educational institution facilities and infrastructure, and other educational components can develop individual competencies effectively and efficiently.

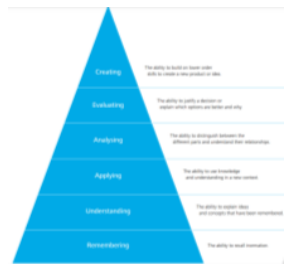

Figure 1 The Bloom-Anderson Taxonomy Model [11]
Students are subjects who are also the main component in school learning activities [12]-[14]. Every learning activity must involve students, but does not always involve the teacher. Books can be a source of learning, practice can be a learning experience. However, without students, each of these activities is meaningless or not a "teaching" activity. According to the online KBBI dictionary, students have the meaning of school children (especially in elementary and high schools); protege; student; learners. The student as an individual has various characteristics that may be the same or different from other students. Characteristics inherent in students are divided into two types, namely the status of origin and status achieved or status obtained within a certain period [15]. Characteristics or status of origin include name, gender, age, name of parent or guardian, address, learning style, hobbies, while examples of status achieved include: education, occupation, position, skills, and abilities. Therefore, student characteristics are an indirect component of learning activities.

Learning that is structured based on the characteristics of students is known as differential learning or differentiated learning. Unlike the general view, differentiated learning is very troublesome because educators must develop learning scenarios that are tailored to each student's characteristics. However, the main principle is to bring the learning model closer to the personal experience of students. This can help students to internalize the learning activities that are followed. When students are able to see learning activities from the point of view of their personal experience, then the process of knowledge, understanding, application, analysis, and evaluation of learning materials is easier to do. The preparation of the context of learning activities that are far from students' experience requires high imagination and capture power from students. This challenge is getting bigger and harder, starting from the level of basic education, secondary education, and higher education. Along with the increasingly complex materials and competencies required to be mastered, it is increasingly difficult to bring the learning context closer to students' personal experiences.

Good learning is learning that is able to make students comfortable and happy while studying and get optimal learning outcomes. Learning has four principles, namely, interactive, which means that in a learning process, it is not just teaching but can build interactions between teachers and students and between students. Second, inspirational which means a learning process that allows students to try and do something. Third, challenging which means a learning process that challenges students to develop thinking skills. Fourth, fun, which means a learning process that can develop all the potential of students. Fun learning management is very important to enjoy a conducive learning atmosphere to achieve learning objectives. This is in accordance with the objectives of differential learning, namely helping all students in learning, increasing student motivation, and learning 
outcomes, establishing harmonious relationships between teachers and students, helping students become independent students, and increasing teacher satisfaction [16].

Every policymaker and teacher in educational institutions is required to understand the characteristic profile of students in their institutions so that if students experience academic problems or get poor learning outcomes, the main preference for solving these problems comes from a comprehensive understanding of student profiles [17]. This shows that the characteristics of students' attributes influence the success or failure of students' academic achievement. Periodically, it is necessary to conduct an assessment to find out changes in the characteristics of students, especially those concerning the academic and non-academic competencies of students. This is a challenge as well as an opportunity for creative teachers to develop their own abilities while optimizing the opportunities for student learning success. Based on the explanation above, the research on the differential learning model for students is applied to the Advanced BIPA course, which is a course in the Indonesian Language and Literature Education study program that aims to prepare students as creative and flexible BIPA teachers. Therefore, the use of the differential learning model is very suitable to train the creativity and flexibility of prospective BIPA teachers. The theme of this research is "Application of Differentiated Learning Model in Advanced BIPA Courses." The objectives of this study are (1) to describe the process of identifying the profile of student characteristics in Advanced BIPA courses and (2) to describe the process of developing differentiated learning models in Advanced BIPA courses.

\section{METHOD}

The research method used is the ADDIE model development method. The steps in the Identification of Student Characteristic Profiles include Analyze (identify and analyze the choice of student characteristic profiles); Design (designing indicators and instruments for profiling data); Develop (develop data collection instruments based on the results of expert reviews); Implement (carry out student profile data collection); and Evaluate (analyze and evaluate the results of data collection). The next step is the Differentiated Learning Model Development Phase which includes Analyze (analyze and identify lesson plans and teaching materials that can be "closed" to the experiences of students); Design (designing and developing materials, methods, strategies, assessments, evaluations, and learning tools utilizing student profiles); Develop (develop learning tools according to expert input); Implement (applying a differentiated learning model in Advanced BIPA courses); and Evaluate (analyze and evaluate the learning process). Here is the ADDIE model chart.

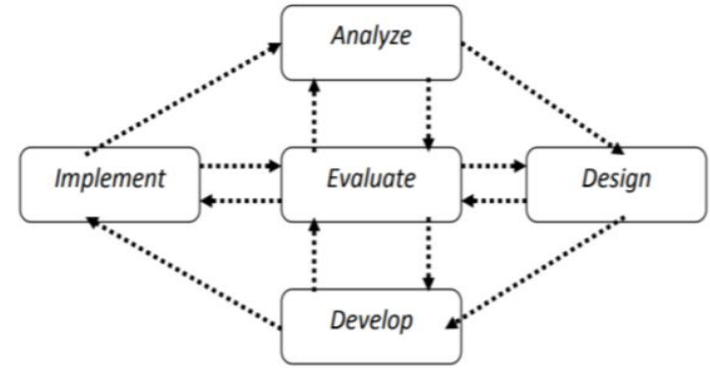

Figure 2 ADDIE Model

Data on the characteristics of students is moving data that develops, changes, gets higher or even decreases depending on the nature of each characteristic and the pattern of its development along with changes in age, education level, and economic level, patterns of association and social life, as well as environmental conditions. Data on individual characteristics in the form of personal profiles should be recorded since the individual enters the initial education bench and updated periodically so that the development of individual characteristics can be monitored and used as the basis for implementing learning at every level of education.

Language experts and learning experts validated the research data collection instrument to ensure the use of Indonesian according to applicable standards and the adequacy of the information needed to prepare learning tools. After being validated, the instrument was improved and then distributed to participants in the Advanced BIPA course.

\section{RESULT AND DISCUSSION}

Differentiated learning is an attempt to adjust teaching and learning activities to meet each individual's learning needs [18]. The scope of the implementation of differentiated learning consists of creating an attractive learning environment, setting learning objectives that are easy to understand and learn, and conducting continuous assessments, responding to the learning needs of each individual, and maintaining effective classroom management. Tomlinson states that the learning needs of each individual are divided into three aspects, namely, student learning readiness (readiness), student interest (motivation), and student learning profile (student characteristic) [18]. Readiness is the capacity to learn new material. Interest is one of the important motivators for students to be "actively involved" in the learning process. The student learning profile is related to many factors, such as language, culture, health, family circumstances, and other specificities. The aspects mentioned by Tomlinson are part of the individual characteristics of students or students [18]. The main purpose of mapping the learning needs of students based on the characteristics of students is to provide opportunities for students to learn 
naturally and efficiently so that the probability of learning success is higher.

The procedure for preparing learning plans before the implementation of lectures includes 1) planning learning objectives, 2) planning learning activities, 3) preparing teaching materials, methods, media, and evaluating learning activities. Then at the first meeting, data collection on student characteristics was carried out based on the profile of the characteristics of the students according to Tomlinson, then an instrument was compiled that functions to retrieve learning profile, learning interest, and learning readiness using the google form application [18]. The following is an example of a self-assessment instrument for taking student profile data.

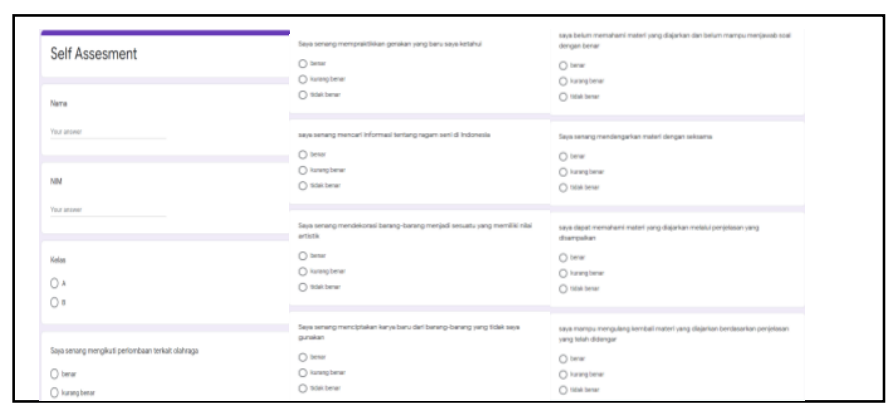

Figure 3 Self-Assessment Instrument

The results of data collection are then quantified in the form of percentages to determine the tendency of the characteristic profile of students in Advanced BIPA courses based on their learning profile, learning interest, and learning readiness. The data taken is in accordance with the needs or learning needs. This is mainly associated with various experiences of students, hobbies, routine activities, interesting activities, places and events related to personal experiences, The results of data collection are then quantified in the form of percentages to determine the tendency of the characteristic profile of students in Advanced BIPA courses based on their learning profile, learning interest, and learning readiness. The data taken is in accordance with the needs or learning needs. This is mainly associated with various experiences of students, hobbies, routine activities, interesting activities, places and events related to personal experiences, events or experiences from other parties but very memorable for students, as well as various inputs and suggestions from students, events or experiences from other parties but very memorable for students, as well as various suggestions from students.
Table 1. Learning Interest

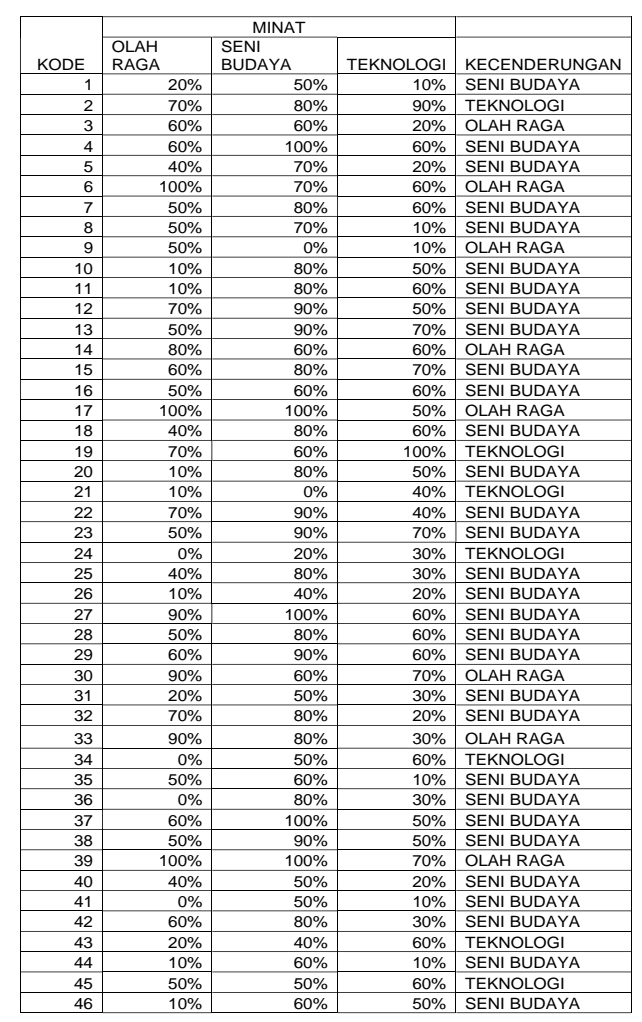

Table 2. Learning Readiness

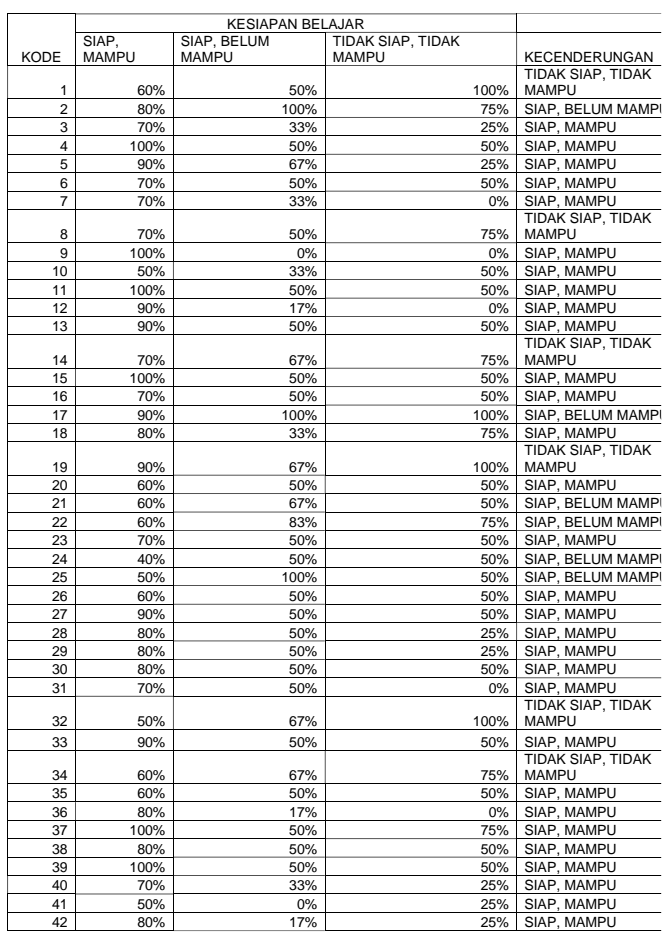


Table 3. Learning Style

\begin{tabular}{|c|c|c|c|c|}
\hline \multirow[b]{2}{*}{ KODE } & \multicolumn{3}{|c|}{ KESIAPAN BELAJAR } & \multirow[b]{2}{*}{ KECENDERUNG, } \\
\hline & AUDITIF & VISUAL & KINESTETIK & \\
\hline 1 & $100 \%$ & $90 \%$ & $50 \%$ & AUDITIF \\
\hline 2 & $70 \%$ & $100 \%$ & $100 \%$ & VISUAL \\
\hline 3 & $80 \%$ & $50 \%$ & $80 \%$ & AUDITIF \\
\hline 4 & $100 \%$ & $100 \%$ & $100 \%$ & AUDITIF \\
\hline 5 & $90 \%$ & $90 \%$ & $100 \%$ & KINESTETIK \\
\hline 6 & $90 \%$ & $90 \%$ & $60 \%$ & AUDITIF \\
\hline 7 & $90 \%$ & $100 \%$ & $90 \%$ & VISUAL \\
\hline 8 & $60 \%$ & $80 \%$ & $60 \%$ & VISUAL \\
\hline 9 & $100 \%$ & $100 \%$ & $100 \%$ & AUDITIF \\
\hline 10 & $100 \%$ & $100 \%$ & $40 \%$ & AUDITIF \\
\hline 11 & $100 \%$ & $100 \%$ & $60 \%$ & AUDITIF \\
\hline 12 & $100 \%$ & $100 \%$ & $100 \%$ & AUDITIF \\
\hline 13 & $100 \%$ & $100 \%$ & $90 \%$ & AUDITIF \\
\hline 14 & $70 \%$ & $100 \%$ & $100 \%$ & VISUAL \\
\hline 15 & $90 \%$ & $100 \%$ & $90 \%$ & VISUAL \\
\hline 16 & $90 \%$ & $100 \%$ & $100 \%$ & VISUAL \\
\hline 17 & $100 \%$ & $100 \%$ & $100 \%$ & AUDITIF \\
\hline 18 & $80 \%$ & $90 \%$ & $80 \%$ & VISUAL \\
\hline 19 & $80 \%$ & $100 \%$ & $90 \%$ & VISUAL \\
\hline 20 & $100 \%$ & $90 \%$ & $90 \%$ & AUDITIF \\
\hline 21 & $100 \%$ & $100 \%$ & $60 \%$ & AUDITIF \\
\hline 22 & $100 \%$ & $90 \%$ & $70 \%$ & AUDITIF \\
\hline 23 & $100 \%$ & $100 \%$ & $90 \%$ & AUDITIF \\
\hline 24 & $80 \%$ & $90 \%$ & $0 \%$ & VISUAL \\
\hline 25 & $50 \%$ & $70 \%$ & $50 \%$ & VISUAL \\
\hline 26 & $70 \%$ & $100 \%$ & $90 \%$ & VISUAL \\
\hline 27 & $100 \%$ & $100 \%$ & $90 \%$ & AUDITIF \\
\hline 28 & $70 \%$ & $100 \%$ & $80 \%$ & VISUAL \\
\hline 29 & $70 \%$ & $90 \%$ & $70 \%$ & VISUAL \\
\hline 30 & $100 \%$ & $100 \%$ & $100 \%$ & AUDITIF \\
\hline 31 & $100 \%$ & $70 \%$ & $60 \%$ & AUDITIF \\
\hline 32 & $70 \%$ & $90 \%$ & $70 \%$ & VISUAL \\
\hline 33 & $90 \%$ & $100 \%$ & $100 \%$ & VISUAL \\
\hline 34 & $100 \%$ & $100 \%$ & $90 \%$ & AUDITIF \\
\hline 35 & $70 \%$ & $90 \%$ & $60 \%$ & VISUAL \\
\hline 36 & $90 \%$ & $100 \%$ & $90 \%$ & VISUAL \\
\hline 37 & $30 \%$ & $100 \%$ & $100 \%$ & VISUAL \\
\hline 38 & $100 \%$ & $100 \%$ & $80 \%$ & AUDITIF \\
\hline 39 & $100 \%$ & $100 \%$ & $100 \%$ & AUDITIF \\
\hline 40 & $80 \%$ & $100 \%$ & $80 \%$ & VISUAL \\
\hline 41 & $60 \%$ & $80 \%$ & $100 \%$ & KINESTETIK \\
\hline 42 & $90 \%$ & $100 \%$ & $0 \%$ & VISUAL \\
\hline 43 & $90 \%$ & $100 \%$ & $70 \%$ & VISUAL \\
\hline 44 & $50 \%$ & $50 \%$ & $50 \%$ & AUDITIF \\
\hline 45 & $90 \%$ & $100 \%$ & $100 \%$ & VISUAL \\
\hline 46 & $80 \%$ & $100 \%$ & $100 \%$ & VISUAL \\
\hline 47 & $80 \%$ & $50 \%$ & $60 \%$ & AUDITIF \\
\hline
\end{tabular}

Then the next stage is the revision or adjustment of the lesson plan that has been prepared based on the results of the analysis of the characteristics of students in advanced BIPA courses. Along with the demands of differentiated learning in accordance with the conditions and characteristics of students, teachers are required to play a more dynamic and creative role. To optimize learning and student learning outcomes, learning activities are needed that are in accordance with the learning needs of students. Adjustment of learning scenarios can take advantage of one of the characteristics or several profile attributes in common with other individuals. Table 4 below shows how learning scenarios are created and structured based on students' interests. This proves that the availability of student characteristic profiles is able to encourage creativity and innovation from teachers.
Table 4. Learning scenario based on learning interest

\begin{tabular}{|c|c|c|c|}
\hline Minat & Olahraga & $\begin{array}{l}\text { Kesenian } \\
\text { (Prakarya) }\end{array}$ & Sains \\
\hline Nama murid & $\begin{array}{l}\text { Rudi } \\
\text { Ali } \\
\text { Iwan } \\
\text { Najib } \\
\text { Rina }\end{array}$ & $\begin{array}{l}\text { Susi } \\
\text { Rini } \\
\text { Lolly } \\
\text { Wawan } \\
\text { Robert }\end{array}$ & $\begin{array}{l}\text { Aep } \\
\text { Anisa } \\
\text { Lutfi } \\
\text { Seli } \\
\text { Yanti }\end{array}$ \\
\hline Produk & $\begin{array}{l}\text { Membuat } \\
\text { tulisan prosedur } \\
\text { tentang } \\
\text { bagaimana } \\
\text { cara } \\
\text { menggiring } \\
\text { bola dalam } \\
\text { permainan } \\
\text { sepak bola. }\end{array}$ & $\begin{array}{l}\text { Membuat } \\
\text { tulisan prosedur } \\
\text { tentang } \\
\text { bagaimana } \\
\text { cara membuat rumah- } \\
\text { rumahan dari stik es } \\
\text { krim. }\end{array}$ & $\begin{array}{l}\text { Membuat } \\
\text { tulisan } \\
\text { prosedur } \\
\text { tentang } \\
\text { bagaimana } \\
\text { cara } \\
\text { membuat } \\
\text { rangkaian } \\
\text { listrik paralel } \\
\text { dan } \\
\text { seri. }\end{array}$ \\
\hline
\end{tabular}

The preparation of the profile of the characteristics of students needs to involve the family environment, school environment, and community environment as subjects as well as validators of instruments and instrument results. This is in line with the principle of education starting from the smallest environment, namely the family, then involving wider educational environments, both formal and informal. Without the participation of these various parties, there will be a void in the nature of learning in students. The role of the family cannot be replaced by the school, the state cannot take the role of the community. Each environment has an educational role and function that can only be carried out optimally by that environment [19]. Whatever permissive reasons are made to release his responsibilities, the biggest impact as a consequence must be borne by students as victims.

Another example of the less than optimal use of student characteristic profiles is based on the experience of researchers as training instructors for prospective principals and training for strengthening school principals of elementary school in Surabaya City, Malang Regency, Sidoarjo, and surrounding areas. It is known that teacher knowledge and understanding of student characteristics is still lacking. Limited to the components that are assessed and filled in on report cards or student learning outcomes reports. In addition, generally, knowledge about the characteristics of students is only used as a means of communicating and evaluating subjects with parents or guardians of students at the end of the semester. Understanding the characteristics of students has not yet reached the stage of being used to form creative teachers according to the needs and abilities of students. It is the basic capital to ensure the success of student learning, for example students' value in Indonesian and other languages is lacking, so the teacher needs to be suspicious if one or more of the student's language skills are still weak, so it needs to be clarified through a special assessment. Language skills include listening skills, reading skills, writing skills, and speaking skills. If the ability of students to listen and speak is lacking, the teacher must take advantage of students' reading 
and writing skills in various subjects to strengthen students' understanding. Using listening and speaking skills, these students face two main challenges: their weaknesses in listening and speaking and understanding the science being taught. Therefore, the chances of success of students in these subjects are getting lower.

\section{CONCLUSION}

The characteristic profile of students in Advanced BIPA courses based on their learning profile, learning interest, and learning readiness. The data taken is in accordance with the needs or learning needs. This is mainly associated with various experiences of students, hobbies, routine activities, interesting activities, places, and events related to personal experiences. Along with the demands of differentiated learning in accordance with the conditions and characteristics of students, teachers are required to play a more dynamic and creative role. To optimize learning and student learning outcomes, learning activities are needed that are in accordance with the learning needs of students. Adjustment of learning scenarios can take advantage of one of the characteristics or several profile attributes in common with other individuals. This proves that the availability of student characteristic profiles is able to encourage creativity and innovation from teachers.

\section{REFERENCES}

[1] M. R. B. Bara, C. Yusuf, and A. Wulandari, "Materi Ajar Membaca Teks Bermuatan Kesantunan: BIPA Level I," Repetisi Ris. Pendidik. Bhs. dan Sastra Indones., vol. 4, no. 1, pp. 29-33, 2021.

[2] N. A. Astriani, L. S. Sulistyaningsih, and R. Rahma, "Penerapan Metode Latihan Berbantuan Media Puzzle Maker Da. Lam Pembelajaran Kosakata Untuk Bipa Tingkat Dasar.” Universitas Pendidikan Indonesia, 2020.

[3] S. Wicaksana and I. A. Basuki, "Analisis Soal Latihan Keterampilan Membaca Dalam Bahan Ajar BIPA Sahabatku Indonesia Tingkat A1," BASINDO J. Kaji. bahasa, sastra Indones. dan pembelajarannya, vol. 3, no. 2, pp. 261-270, 2019.

[4] N. M. C. P. Lestari, I. M. Sutama, and I. D. G. B. Utama, "Pengembangan Media Pembelajaran Visual bagi Pebelajar BIPA Pemula di Undiksha," J. Pendidik. Bhs. dan Sastra Indones. Undiksha, vol. 8, no. 1, 2019.

[5] M. Yahya and K. Saddhono, "Hubungan penguasaan kosakata dengan kesalahan diksi dalam kalimat bahasa Indonesia mahasiswa BIPA level akademik," KREDO J. Ilm. Bhs. dan Sastra, vol. 1, no. 2, pp. 51-68, 2018.

[6] K. F. Amin, "Pengajaran Bahasa Indonesia untuk Penutur Asing (BIPA) dan Pengenalan Budaya Lokal
Bugis-Makassar," J. Pendidik. Indones., vol. 2, no. 6, pp. 1044-1053, 2021.

[7] M. H. Nursyairofi, R. Usman, and G. Susanto, "Korelasi, Motivasi, dan Prospek terhadap Hasil Belajar Bahasa Indonesia Mahasiswa Amerika di Program BIPA," J. Pendidik. Teor. Penelitian, dan Pengemb., vol. 5, no. 9, pp. 1225-1236, 2020.

[8] W. Wiratsih, “Analisis Kesulitan Pelafalan Konsonan Bahasa Indonesia (Studi Kasus terhadap Pemelajar BIPA Asal Tiongkok di Universitas Atma Jaya Yogyakarta)," KREDO J. Ilm. Bhs. dan Sastra, vol. 2, no. 2, pp. 242-255, 2019.

[9] M. Jakubik, "Quo vadis educatio? Emergence of a new educational paradigm," 2020.

[10]I. Cunningham, Self Managed Learning and the New Educational Paradigm. Routledge, 2020.

[11] A. N. Darwazeh and R. M. Branch, "A revision to the revised Bloom's taxonomy," 2015 Annu. ProceedingsIndiana. Vol. 1, vol. 2, pp. 220-226, 2015.

[12]A. Krismanto, "Beberapa teknik, model, dan strategi dalam pembelajaran matematika," Yogyakarta Depdiknas Dirjen Pendidik. Dasar dan Menengah, 2003.

[13] S. Bragg, “'Student voice' and governmentality: The production of enterprising subjects?," Discourse Stud. Cult. Polit. Educ., vol. 28, no. 3, pp. 343-358, 2007.

[14]A. Kruse and R. Pongsajapan, "Student-centered learning analytics," CNDLS Thought Pap., vol. 1, no. 9, 2012.

[15]P. M. Blau and O. D. Duncan, "The American occupational structure.," 1967.

[16]M. Marlina, E. Efrina, and G. Kusumastuti, "Differentiated Learning for Students with Special Needs in Inclusive Schools,” 2019.

[17]J. M. Braxton and A. S. Hirschy, "Theoretical developments in the study of college student departure," Coll. student Retent. Formula student success, vol. 3, pp. 61-87, 2005.

[18]C. A. Tomlinson, How to differentiate instruction in mixed-ability classrooms. ASCD, 2001.

[19] J. D. Finn and K. S. Zimmer, "Student engagement: What is it? Why does it matter?," in Handbook of research on student engagement, Springer, 2012, pp. 97-131. 